\title{
DETERMINANTS OF THE ECODEVELOPMENT OF PROTECTED AREAS IN POLAND - LEGAL AND INSTITUTIONAL
}

Lukasz Poplawski ${ }^{1}$, Assoc. Prof.; MalgorzataRutkowska ${ }^{2}$, Assoc. Prof.

${ }^{1}$ Department of Finance Government, Faculty of Finance and Law, Cracow University of Economics,

${ }^{2}$ Department of Infrastructure of Management, Faculty of Computer Science and Management, Wroclaw University of Science and Technology,

\begin{abstract}
The area covered by protected areas in Poland amounts to $33.1 \%$; the region with the highest percentage of areas covered by them is in the SwietokrzyskieVoivodeship - $62 \%$. These areas are usually landscape parks and protected landscape areas. The basic of development of protected areas should be based on the production of high quality food and food processing. The aim of this paper is to present the problem of ecodevelopment of protected areas in Poland - legal aspects. The work discusses theoretical issues of instruments and institutions with reference to protected areas of Poland. Following the topic, the role of inhabitants and institutions in ecodevelopment of protected areas has been analysed. The problem of strategic management in the context of ecodevelopment has been raised in this paper. Special attention is paid to the participation of the public institutions and the authorities in ecodevelopment of protected areas. The main problems are law and instruments, which should supportecodevelopment of protected areas. The work ends with a brief conclusion. The conclusionsuggeststhat institutional support is very important for development, especially economic instruments.
\end{abstract}

Key words:legal aspects, economic instruments, protected areas, ecodevelopment, Poland.

JEL code: H41

\section{INTRODUCTION - THE REVIEW OF THE CHOSEN ECONOMIC INSTRUMENTS IN ENVIRONMENTAL PROTECTION}

The economic instruments take a special place among the means of environmental protection as it is more and more frequently expected to solve the problems of threats for the environment mainly economically. Their purpose is to influence the entities indirectly by affecting their financial results, therefore environmental protection stops being a side effect and becomes an important economic activity in the strict sense. The essence of the ecological application means preventative functions.

Simultaneously, considering the realizations of protection priorities, redistribution of financial resources is also crucial. It is based on collecting and transferring financial resources allocated for environmental protection. Apart from that, the functions of the economic instruments include the following functions: stimulating, transferring (earning income) and regulatory. The aim of this paper is to present the problem of ecodevelopment of protected areas in Poland - legal aspects. This paper presents problem of ecodevelopment of protected areas in Poland in the aspect of institutional support. 


\section{Groups and types of economic instruments in environmental protection}

\begin{tabular}{|c|c|}
\hline $\begin{array}{l}\text { Groups of } \\
\text { instruments }\end{array}$ & Types of instruments \\
\hline $\begin{array}{l}\text { Ecological } \\
\text { charges }\end{array}$ & $\begin{array}{l}\text { For taking over land for non-agricultural and non-forest purposes. } \\
\text { For emitting pollution into the air, waste disposal, removal of trees and bushes and for water } \\
\text { uptake and pouring sewage and mine waters including chloride and sulphate compounds into } \\
\text { the waters belonging to the state (or the ground). } \\
\text { Concession fees for looking for and excavating minerals. } \\
\text { Administrative charges, for example, for issuing emission allowances. } \\
\text { Product charges. } \\
\text { Deposit charges. }\end{array}$ \\
\hline Subsidies & $\begin{array}{l}\text { Subsidies from the National Fund for Environmental Protection and Water Management and } \\
\text { voivodeship funds for co-financing undertakings of the pro-ecological character. } \\
\text { Preferential lending rules of ventures connected with environmental protection by the National } \\
\text { Fund for Environmental Protection and Water Management and the Bank for Environmental } \\
\text { Protection. } \\
\text { Income tax credits for investment in environmental protection, VAT credits for using waste of } \\
\text { reprocessing and agricultural tax credits. } \\
\text { Budget subsidies. }\end{array}$ \\
\hline $\begin{array}{l}\text { Financial } \\
\text { incentives } \\
\text { of law } \\
\text { enforcement }\end{array}$ & $\begin{array}{l}\text { Penalties for polluting the air and discharging sewage into ground waters which do not meet } \\
\text { the conditions defined in the so-called report of air protection and water permit, for exceeding } \\
\text { permitted noise levels, penalties for inappropriate waste disposal, for removing trees and } \\
\text { bushes without the required consent of the local administrative organ and others } \\
\text { Collecting penalty interests for untimely payments and ecological penalties } \\
\text { Enforced penalties and ecological fees in accordance with the regulations on enforcement } \\
\text { procedures in administration }\end{array}$ \\
\hline $\begin{array}{l}\text { Deposit and } \\
\text { guarantee } \\
\text { systems }\end{array}$ & $\begin{array}{l}\text { Deposit fee. } \\
\text { Guarantee. }\end{array}$ \\
\hline $\begin{array}{l}\text { Creation of } \\
\text { the market }\end{array}$ & $\begin{array}{l}\text { Transferable permits (trade of pollution emission allowance). } \\
\text { Interventions in the market mechanisms. } \\
\text { Defining financial responsibility and creating the market of insurance against the ecological } \\
\text { risk. }\end{array}$ \\
\hline $\begin{array}{l}\text { Direct } \\
\text { regulations }\end{array}$ & $\begin{array}{l}\text { Legal norms. } \\
\text { Planning rules. } \\
\text { Rules of administrative proceedings concerning the use of the natural environment, including } \\
\text { bans and orders. }\end{array}$ \\
\hline
\end{tabular}

Source: Gorka K. Poskrobko B, Radecki W., Ochronasrodowiska. Problemyspoleczne, ekonomiczneiprawne, PWE, Warszawa 2001, p. 78-153; Bernaciak A., Gaczek W. M., Ekonomiczneaspektyochronysrodowiska, Wyd. AE, Poznan 2002, p. 134-186

The economic instruments binding in Poland can be grouped in the following way ${ }^{1}$.

- Fees:

- for taking over land for non-agricultural and non-forest purposes,

- for emitting pollution into the air, waste disposal, removal of trees and bushes and for water uptake and pouring sewage and mine waters including chloride and sulphate compounds into the waters belonging to the state (or the ground), the socalled emission charges,

- concession fees for looking for and excavating minerals,

- for administrative charges, for example, for issuing emission allowances,

- product charges which currently refer to packaging and products especially harmful to the environment in Poland. They are charged to entrepreneurs who are obliged to recover and recycle given waste. The difference in the form of this fee is paid by the entrepreneurs and goes to special funds for environmental protection,

${ }^{1}$ Gorka K., Ekonomiczneaspektyochronysrodowiska. In: Ochronasrodowiska. Problemy społeczne, ekonomiczne i prawne, PWE, Warszawa, 2001, p.23. 
deposit fees which burden products harmful to the environment. They are returned if a purchaser returns a used product to the seller. This fee is charged in Poland, for example, to batteries. Deposits burden, for instance, packaging of chemical substances especially damaging to the environment, therefore they are regulated by law. The deposit is returned if the thing burdened with it is returned.

- Subsidies:

- budget subsidies and loans of the funds for environmental protection and water management for co-financing undertakings of the pro-ecological character,

- preferential lending rules of ventures connected with environmental protection,

- income tax credits for investment in environmental protection, VAT credits for using waste of reprocessing and agricultural tax credits,

- financial incentives supporting law enforcement, for example, penalties,

- instruments creating the market (transferable permits, ecological insurance).

Nowadays there is also a fee connected with car recycling, the so-called wreckage fee.

The incentives supporting law enforcement are the instruments active before violation of environmental protection law or after violating it. Two elementary categories of incentives are used: penalties for violation of conditions of environmental protection and ecological deposits used if there is a probability of a breach of regulations in force; however, any subventions, subsidies and grants limit the use of the basic rule in environmental protection that "the polluter pays." The economic instruments are of a price character since they are most often defined in the form of unit fees, which mean a concrete cost burden for the user of the environment increasing together with the degree of environmental use ${ }^{1}$.

\section{Institutional support fordevelopment of protected areas in Poland ${ }^{2}$}

Development of protected areas is also based on their institutional support. The importance of organizations both governmental and non-governmental is of a great importance for the discussed areas as for the given developmental standards. First of all, cooperation of state institutions with local communities in the protected areas should be based on creation of legal and financial bases to support pro-ecological activity of entities. This support is provided by numerous groups of factors. Improvement of the condition of the environment and its protection would not be possible if the support instruments did not exist. Development of the protected areas is connected with a lot of factors. Nowadays the most essential ones, apart from management and financing of pro-ecological actions in the given area, include the human and social capital. Regardless of the factors which we pay attention to, all of them should be based on the present law and its organs. In order to be able to implement these actions, they have to be previously recognized and included in the local action programmes. The impact of the given developmental factor on the given natural area will also depend on the form of the nature conservation. Different actions will be taken in the area of the national park and others in the area of the protected landscape.

The economic factors can be divided into organisational - managing and financial ones. The organisational and managing factors are connected with the institutions supporting development of protected areas. First of all, they are governmental and non-governmental organisations on the local, regional, national and international level. The governmental organisations supporting 
development of protected areas cooperate with the Ministry of the Environment and the organs subordinated to it. These organisations include:the Ministry of Agriculture and Rural Development, the Ministry of National Education, the Ministry of Finance, the Ministry of Science and Higher Education, the Ministry of Regional Development, the Agricultural Market Agency (AMA), the Agency for Restructuring and Modernisation of Agriculture (ARMA), the agricultural advisory centres (AAC).

The non-governmental organisations also support pro-ecological actions in the areas covered by protection. According to the data in the National Business Registry Number (REGON), 45.000 associations and over 7.000 foundations are registered in Poland. The total number of the members of these organisations is over 8 million, which makes up $20 \%$ of the whole society. In spite of appearances, this number is not high in comparison with other countries. These organisations function individually or create bigger networks like the Polish Green Network. The organisations cooperate with other entities, for instance, the State Forests, self-governments and public entities. Most of the non-governmental organisations are associations. The main nongovernmental organisations operating in Poland include:

- the League for Preservation of Nature (LOP) was formed in Cracow,

- the Polish Ecological Club (PKE) was formed in Cracow in 1980.

Moreover, there are local non-governmental organisations. The funds supporting development of protected areas include, for example:

- the National Fund for Environmental Protection and Water Management (NF) and Voivodeship Funds of Environmental Protection (FOS);

- international organisations supporting environmental protection, for instance:

Greenpeace, World Wildlife Fund (WWF), the World Conservation Union (IUCN).

The financial factors concerning the range of financing especially environmental protection have already been presented in the previous subchapter. Furthermore, it should be mentioned here that the existing European resources can and are used for development of protected areas.

The planning factors make up the second group, which can be divided into spatial and strategic ones. First of all, the spatial factors include: the study of conditions and directions for land planning and the local plan of land planning.

The study of conditions and directions for land planning is a document defining the planned management of the whole territory of the commune in the general way, which includes information on the localisation of the areas designated for construction, the course of main transport routes, protected areas, etc. The study is accepted by the resolution of the Council of the Commune. It is a basis to elaborate the local land management plan and is a document preceding the realization of this plan. It includes the rules of land policy of the given place and integrates program documents and visions connected with economic and social development. This document includes a very wide scope of information on the natural environment of the commune, its society and economy. The discussed Study includes information in relation to the social and economic situation and directions of spatial development of the commune.

The local land management plan is a basis for "spatial planning" in the commune. According to art. 14 of the act of the $27^{\text {th }}$ of March, 2003 on land use planning and management, it is a local legal act the arrangements of which (the local land management plan) take the provisions of special regulations concerning the area of the subject covered in the plan into account. Such special regulations include, for instance: the regulations of the act on environmental protection, the 
regulation concerning the given national park or landscape park as well as the protection plans of the given park. The obligation of drawing up this plan starts at the moment of establishment of the protection plan of the national park or the landscape one. While constructing the local plans, it is crucial to decide on the study of conditions and directions for land planning of the commune, which are binding on pain of invalidity of the plan. The protection plan of the park is superior in relation to the Study.

The self-governmental authorities are obliged to define the possessed natural resources and to valorise each natural element considering its vulnerability to civilisation progress. Its purpose is to elaborate such a land management plan the arrangement of which take natural resources into account to such a degree so that human activities will not contribute to deformation of the structure of natural resources. The communes situated in the protected areas of the SwietokrzyskieVoivodeship do not often have the elaborated land management plans. In individual documents there are the land management plans of the areas of the communes, in which a lot of natural conditions are also considered.

The strategic documents include: the Strategy of development of the communes which comprise of the main aims and conditioning of their development for the next 10-15 years during the changing internal and external conditionings. The strategy of development of the commune is programming of future actions. The essence of the strategy is prioritization of the purposes as there is never a possibility of a simultaneous realization of all the needs. In the first place, the aims making the future development easier should be implemented. The aim of the elaboration of the strategy is to prepare such an own document of the local authorities, owing to which they will be able to organize their future actions reasonably. The strategy should become the basis to conduct proper policy by individual entities acting in the local area, and especially by the public authorities. The basis of the strategy of development of the commune should be a plan of the maximum use of inner resources of the potential of the local entities as well as the advantages of its location. The strategy should be based on the detailed recognition of existing resources of the commune and values of its localization. In case of existing protected areas, the strategy should take spatial planning and programming, realizations and controls of business activity into account in accordance with the principles of sustainable and balanced development.

Legally protected areas express superiority of environmental protection over the entities and business activity in this area. The nature as a whole and its each element separately is a value in its own right in the legally protected areas, which human activity must subordinate to. The national and landscape parks, the nature reserves and the areas of the protected landscape create the national system of the protected areas. This system makes up the spatial structure of mutually completing forms of nature protection, connected with ecological corridors (the Act on protection ... 2004). Therefore, the task of the developmental strategy of the commune in protected areas is to elaborate an appropriate compromise between economic development and protection of natural environment.

The plan of environmental protection is a document taking all the strategic aims of ecological policy into account discussing the issues of natural resources protection and the detailed issues of environmental protection of the given region. According to the Act on the Right to protect the environment, the voivodeship, poviat and commune authorities are obliged to make plans of environmental protection. These plans are prepared every 4 years, including the ecological aims and priorities, the type and the schedule of pro-ecological actions and the resources necessary to 
achieve these goals. Each self-governmental unit has to make a report of feasibility of the plans every 2 years. The following main priority aims are often found in the Programmes of Environmental Protection of the communes in the protected areas of the SwietokrzyskieVoivodeship: improvement of the state of natural environment (supporting development of the infrastructure protecting the environment, constructing water intake stations and water supply systems, organizing waste management, building waste water treatment plants and storage reservoirs, exchanging coal-fired boiler houses into gas ones), increase in ecological awareness (a decrease in harmful pollution emission), improvement of landscape and aesthetic values (development of mining excavations, establishment of nature reserves).

The plan of waste management is drawn up on the basis of the act on waste of 27.04.2001 (the Official Journal no. 62, item 628). This Act introduces the obligation to elaborate the plans on the national, voivodeship, poviat and commune level. The discussed plan defines:

- a present state of waste management,

- foreseen changes in the scope of waste management,

- actions intending to improve the situation in relation with waste management,

- financial instruments for the realization of desired aims,

- a monitoring system and an assessment system of the realization of tasks, and especially a type, number and source of waste, which is to undergo the process of recovery or disposal,

- a localization of existing installations and devices for recovery or disposal of waste together with the list of entities doing business in this scope,

- actions intending to prevent production of waste or limits to the amount of waste and their negative influence on the environment as well as a proper procedure how to manage it, including a limit to the amount of biodegradable waste included in municipal waste brought to landfills,

- a designed system of waste management.

The third group are the statutory factors, including legislative ones. The elementary sources of law commonly binding in Poland in the scope of environmental protection are the following: the Constitution of the Republic of Poland, acts, resolutions and provisions as well as other regulations resulting from the acts. The legal acts include the guidelines as for the manner of using the nature, orders, bans and limits. The Polish legal acts are regulated by the international law of environmental protection.

The Constitution of the Republic of Poland of the $2^{\text {nd }}$ of April, 1997 (the Official Journal of 1997 no. 78 , item 483) "protects the national heritage and provides environmental protection, following the rule of sustainable development" (art. 5). Moreover, the Constitution sanctions the obligation to conduct policy by the authorities providing a contemporary citizen and future generations with ecological security and to support actions of citizens for protection and improvement of the environmental condition, and it imposes an obligation on each citizen to take care of the environment and be responsible for causing the deterioration of the environment (art. 74 and art. 86).

The Polish ecological law regulates the status of the areas and the objects with special natural values. The most important acts in this scope include:

- the Act of environmental protection of the $16^{\text {th }}$ April, 2004 (the Official Journal no. 92, item 880), 
- the Act on the Right to protect the environment of the $27^{\text {th }}$ of April, 2001 (the Official Journal no. 62 item 627 with subsequent amendments the Official Journal 03.190 .1865 of the $7^{\text {th }}$ of November 2003).

These acts are the basis to issue provisions and regulations as well as to adopt resolutions concerning the formation of a given type of areas, implement species protection for plants and animals as well as drawing up protection plans for national parks, landscape parks, and nature reservoirs. Here there are also all the obligations resulting from the international agreements and resolutions concerning protected areas.

The social factors include welfare and ecological awareness with education.

The important element of the formation process of the field of environmental protection is ecological awareness of society. The provision of common access to information on the environment and ecological education conducted properly can contribute to improvement of the quality of the environment to a greater degree. Such a conduct can also decrease a negative human impact on the nature. A human being has subjects discussing the issues of environmental protection on every level of education. Kindergartens, elementary schools, junior and senior secondary school as well as universities offer subject providing knowledge on this issue in their curriculum. Ecological topics are implemented in certain lessons through popularisation of ecological subject matter, for instance, through solving tasks, preparing wall newspapers in relation to the above mentioned subject area.

The National Strategy of Ecological Education realizes the following aims for sustainable development through:

- Raising complete awareness and increasing interest of the society in commonly connected economic, social, political and ecological issues,

- Enabling each man to acquire knowledge and skills necessary to improve the condition of the environment,

- Creating new models of behaviour, shaping attitudes, values and believes of individuals, groups and societies, taking care about the quality of the environment into consideration.

- School education from kindergarten education to higher one includes the whole range of actions and content, resulting from the age and direction of education as well as the regulations of the Act - the Right to protect the environment of 2001.

Until recently the ecological awareness in Poland was far from satisfactory, for example, devastated forests prove it. The forms of environmental protection limiting the use of some areas contribute to the fact that people start to pay more attention to the natural environment to a greater degree. The cases of devastation of the natural environment are discussed more and more frequently in everyday life, the press, the radio or TV. A lot of organizations are formed supporting development and taking care of protection of the areas especially valuable in terms of the nature. Numerous competitions, exhibitions and trainings concerning environmental protection are organized. The days connected with ecology are celebrated both in the country and in the world.

Education is provided by many institutions dealing with ecological teaching professionally. Those organised by national parks or landscape parks play the special role among various types of educational and information centres. Additionally, schools, plants and ecological organizations prepare ecological competitions. They are of a regional or national character. They are art competitions, for example, promoting a given ecological campaign, photo competitions depicting the beauty of animate and inanimate nature, showing naturally devastated places, music 
competitions such as an ecological song, a competition of ecological knowledge. For example, they are a competition for a slogan promoting the idea of the European Network of Areas NATURA 2000, a contest "the Black Forest" etc. What is more, educational activity is often conducted for tourists and the youth in national and landscape parks as a completion of school education. The national parks have special routes the so-called "didactic paths," museums and ecological education centres. A lot of information and educational materials are published and the access to websites is provided. Currently, 10 Polish parks have educational centres, and 17 parks run museum activity. Educational centres of national parks deal with environmental education of students from local schools of different levels. You can learn in such educational centres what a given entity does for the natural environment and how they try to protect it.

\section{Discussion}

First of all, the social factors mean welfare of the country, territorial self-government units and other budget institutions which largely contributes to improvement of living conditions of inhabitants in rural areas, including protected areas. The additional source of income of families such as benefits or disability pensions support the elementary household budget. The appropriately high family budget residing in protected areas conditions their development. The financial resources cover the needs of inhabitants, for instance, connected with the zone of environmental protection such as education (books, trainings, studies, courses), ecological awareness (through the constant access to the Internet). Social benefits from the commune budgets contribute to lowering poverty in these areas, owing to which the general living standards of the local community are enhanced, which consequently leads to development of protected areas. The social help is based on giving and granting benefits such as invalidity, attendance, for single parents, special social benefits, family benefits, for the unemployed, etc. The financial resources can also be allocated from disability pensions: invalidity, attendance, inheritance, as well as from scholarships granted for the students living in given communes from the commune budget and from the European funds. The social financial resources are mainly from the commune budget, the state budget and the European Union one. To a much lesser extent, their source can come from other state and non-governmental institutions, as well as from private persons and foundations. Furthermore, according to a lot of authors, the political factors can be distinguished within the generally accepted factors.

The political approach to the issues of environmental protection is realized by political parties. Sustainable development assumes integration of social, ecological and economic aims, for instance, by implementing the ecological tax reform. These parties indicate the necessity of the effective implementation of the rule the one who pollutes should pay as polluters have to bear full costs of polluting the environment. The implementation of eco-social market economy also brings about development of small and medium-sized enterprises and new workplaces in such sectors of the economy as the power industry of renewable sources of energy, ecological agriculture, ecological building, environmentally-friendly transport. The parties emphasise educational matters of the society, also in the field of environmental protection, waste management and production of electricity from renewable sources.

"Environmental pressures have increased with the economic growth and in order to reduce a negative environmental effect, more attention is paid to the market based on instruments (environmental taxes, tradable permits etc.). Similarly to many countries, the implementation of 
the ecological tax reform has also started in Estonia" (EdaGruner et al., 2009), this sentence is a starting point to consider economic instruments in environmental protection. It should be noted that there is not a standardized system in this scope although the groups of instruments (Table 1) are the same in many countries. The analyses carried out by Th. Panayotou (1994) confirm a vast variety especially in the field of indirect instruments.

One should emphasize that "environmental taxes are still relevant economic instruments to facilitate the development of environmentally friendly behaviour of consumers and producers and to enhance economic efficiency" and they are the most important (EdaGruner et al., 2009; Panayotou Th., 1994). The example of the Czech Republic described by J. Kovar (2018) with regard to economic instruments proves that their use in view of functioning the tax system and the macroeconomic structures is a serious problem in the economy.

The development of protected areas ought to be supported and treated as an alternative source of income for farmsteads and rural areas. A similar point of view was presented byI. Bruksle and R. Zvirgzdina (2017), E. Gaule and G. Zilinskas (2013), M. Parlinska (2016), M.Parlinska and S.HassaniTaibi (2016), A.Parlinska (2007, 2010) I. Pilvere (2012), and Y. Yusnitaet al. (2012).

\section{Conclusion}

The institutional support is an essential element of support of eco-development, therefore the respondents were asked how they evaluate given institutions in the context of development of their communes (Poplawski, 2009). The interviewees in the communes of Zlota, Stopnica, Radoszyce, Michalow and Kije indicated that the authorities of all the levels of administration have a positive influence on development of their commune. The lower the level the self-government was, the friendlier authorities of the commune were. Nevertheless, apart from the above mentioned communes, the dwellers of all the other ones assessed their commune authorities very positively, which proves their trust in them (Poplawski, 2009).

Simultaneously, the land management is essential for the introduction of eco-development in protected areas, which conditions all the developmental processes in the long run, but also the instruments of environmental protection. Having analysed only the chosen economic instruments in Poland.

1) The conclusions are as follows.

2) The economic instruments are a tool to implement the ecological policy of the state and stimulate development of protected areas.

3) The tax differentiation applied in Poland frequently seem to be accidental and are not of a coherent character, but the tax system should support ecological attitudes - a lot of actions should be taken in this regard in the future.

4) The instruments applied in environmental protection should stimulate or even force protective undertakings, as well as minimise the social expenses of environmental protection, especially in the scope of the entities situated in protected areas.

\section{Bibliography}

1. Bruksle, I., Zvirgzdina, R. (2017).Problems of Pricing as a Competitiveness Tool in Latvian Business Environment,

2. Proceedings of the 2017 International Conference "Economic Sciences for Rural Development" No 45 Jelgava, LLU ESAF, 27-28 April 2017, pp. 21-29.

3. Gaule, E., Zilinskas, G. (2013). E- Governance Development External Factors Analysis: Lithuanian Municipalities On Rural-Urban Divide, Economic Sciences for Rural Development, No. 31 Integrated and Sustainable regional development, Jejgava, pp. 146-152. 
4. Gruner, E., Salu, K., Oras, K., Nommann, T. (2009).Environmental Taxes- economic Instruments for Environmental Protection, EestiStatistikaKvartalikiri. 3/09. Quarterly Bulletin of Statistics Estonia, pp. 16-21.

5. The Constitution of the Republic of Poland of $2^{\text {nd }}$ of April, 1997 (the Official Journal 1997 no. 78, item 483).

6. Parlinska, A., 2007, Tax and Social Security Systems in Polish Agriculture, The Proceedings of TheInternational Conference Competitiveness and European Integration, October 26-27, 2007 CLUJNAPOCA, ROMANIA, Regional and Rural Economics, pp. 233-239.

7. Parlinska, A., (2010). Public Administration in Poland, [W:] European Union Public Administration and Development Policies and Variations In V-4 Countries pod redakcjaEleonoraMarisova, Slovak University of Agriculture in Nitra, pp. 189-201.

8. Parlinska, M., (2016). Information on the wholesale agricultural market [w:] Materials of the 8th international scientific - practical conference Ganja, Azerbaijan, nr 43, pp. 86-91.

9. Parlinska, M., Hassani,Taibi, S.(2016). Chosen Information Systems for Agriculture in Poland and France [w:] Economic Science for Rural Development, nr 43, pp. 86-91.

10. Pilvere, I. (2012). Support Payment for Agriculture in Latvia Regions, International Journal of Business and Management Studies, Volume 1, No. 1, pp. 553-564.

11. Poplawsk,iL (2009). Poplawski's unpublished dissertation in English (The conditions of eco-development of rural communities in the protected areas of the SwietokrzyskieVoivodeship. The publishing house Wyd. Naukowe PWN. Warsaw.

12. The Act on Environmental Protection of the $16^{\text {th }}$ of April, 2004 (the Official Journal no. 92, item 880).

13. The Act the Right to Protect the Environment of the $27^{\text {th }}$ of April, 2001 (the Official Journal no. 62 item 627 with subsequent amendments the Official Journal 03.190.1865 dated on $7^{\text {th }}$ of November, 2003).

14. Yusnita, Y., Yahaya, I., MohdShaladdin, M., Wan Abd Aziz Wan Mohd Amin (2012). "Community Based Tourism and Quality of Life", Rev. Integr. Bus. Econ. Res. Vol 1(1), www.sibresearch.org/uploads/2/7/9/9/2799227/riber2012-238_335-345.pdf/2014-03-19.

15. Panayotou, Th. (1994).Economic Instruments for Environmental Management and Sustainable Development, International Environment Program Harvard Institute for International Development Harvard University/https://www.cbd.int/doc/nbsap/finance/Panayotou1994EconInstEnvMgSusDev_199EcInsEnvMgS usDev.pdf/2018-03-26.

16. Kovar, J. (2018).Economic Instruments for Environmental Protection/ https://www.czp.cuni.cz/knihovna/undp/modra/M14_kovar2.htm\#IVa/2018-03-26. 